\title{
The Evaluation of Ramadan Fasting Experience of Patients with Gastric Cancer Who Underwent Curative Resection
}

\author{
Küratif Rezeksiyon Uygulanan Mide Kanserli Hastaların Ramazan Oruç \\ Deneyimlerinin Değerlendirilmesi
}

\author{
\Mehmet Fatih Daşıran, \Ahmet Akbaş, \Fatih Göğüş, \Yavuz Selim Angın, \Murat Yıldırım, \\ (D) Emin Daldal, (1) Hasan Dagmura, ismail Okan
}

General Surgery Department, Gaziosmanpasa University Hospital, Tokat, Turkey

\begin{abstract}
Objective: Patients who had curative treatment after a malignant disease frequently ask about their religious practices and especially Ramadan fasting. The aim of this study is to evaluate the survivors of gastric cancer patients whether they keep Ramadan fasting and the health conditions they experienced during the month of Ramadan.

Material and Method: For this cross sectional observational study, first the files of patients who had gastrectomy due to malignancy between January 2011 and January 2018 in Gaziosmanpasa University Hospital were examined retrospectively. The surviving patients were scheduled for a meeting and a questionnaire was conducted in outpatient setting. Patients who were conceiving to fast in next Ramadan were invited for at least 2 visits again within one month before and one month after Ramadan. On their arrival, their weight was measured, laboratory test including albumin, haemoglobin, haematocrit, BUN and creatinine levels were obtained.

Results: $11(21 \%)$ of the 52 interviewed patients kept fasting in 2019 Ramadan. 5 of these patients were able to complete fasting (30 days) and 6 of them could partially (between 1-7 days). There was no weight loss in fasting patients after Ramadan $(p>$ 0.05). In addition, no significant change was found in albumin, haemoglobin, haematocrit and creatinine values after Ramadan $(p>0.05)$. However increase in BUN level was statistically significant $(p<0.05)$.

Conclusion: Health professionals are likely to see fasting patients all over the world and they must be familiar with the physiological and psychological effects of fasting considering the spiritual and religious needs of the patients.
\end{abstract}

Key words: Fasting, gastrectomy, ramadan, spirituality
Öz

Amaç: Malign bir hastalık için tedavi gören hastaların tedavi sonrası akıllarında dini uygulamalar ve özellikle Ramazan orucu hakkında sorular oluşmaktadır. Bu çalışmanın amacı mide kanser ameliyatı olmuş hastaların Ramazan orucu tutup tutamadıklarını ve Ramazan ayı boyunca yaşadıkları deneyimleri değerlendirmektir.

Gereç ve Yöntem: Bu kesitsel, gözlemsel çalışma için öncelikle Gaziosmanpaşa Üniversitesi Hastanesi'nde Ocak 2011-Ocak 2018 tarihleri arasında malignite nedeniyle gastrektomi geçiren hastaların dosyaları geriye dönük olarak incelendi. Hayatta olan hastalar aranarak çalışma hakkında bilgi verildi, katılmak isteyen hastalara hazırlanan anket çalışması uygulandı. Önümüzdeki Ramazan ayında oruç tutmayı isteyen hastalar, Ramazan'dan bir ay önce ve bir ay sonra en az 2 ziyarete davet edildi. Geldiklerinde ağırlıkları ölçüldü, albümin, hemoglobin, hematokrit, BUN ve kreatinin düzeylerini içeren laboratuvar testleri yapıldı.

Bulgular: Çalışmaya katılan 52 hastadan 11'i (\% 21) 2019 Ramazan ayında oruç tuttu. Bu hastalardan 5'i (30 gün) Ramazan orucunu tamamlayabilirken, 6'sı kısmen (1-7 gün arasında) oruç tutabilmiştir. Ramazan sonrası oruç tutabilen hastalarda kilo kaybı olmadı ( $p>0.05$ ). Ayrıca Ramazan sonrası albümin, hemoglobin, hematokrit ve kreatinin değerlerinde anlamlı bir değişiklik saptanmadı ( $p>0.05)$. Ancak BUN düzeyindeki artış istatistiksel olarak anlamlıydı ( $p<0.05)$.

Sonuç: Sağlık çalışanları dünyanın her yerinde oruç tutan hastaları görmektedir. Oruç tutmanın fizyolojik ve psikolojik etkilerini, hastaların ruhsal ve dini ihtiyaçlarını da göz önünde bulundurarak iyi bilmek gerekmektedir.

Anahtar Kelimeler: Oruç, gastrektomi, ramazan, maneviyat

Corresponding (illetişim): Mehmet Fatih Dasiran, Department of General Surgery, Faculty of Medicine, Gaziosmanpasa University, 60030, Tokat, Turkey 


\section{INTRODUCTION}

Gastric cancer is the fifth most common malignancy after lung, breast, colorectal and prostate cancers in the world according to WHO data. It is also the third leading cause of death from cancer after lung and colorectal cancers. ${ }^{[1]}$ Surgery still remains the golden standard of the treatment. Either total or subtotal gastrectomy with lymph node dissection, depending on the location of the tumor provides a survival benefit in the treatment of gastric cancer. ${ }^{[2-4]}$ Letting alone the immediate perioperative morbidity, patients may experience specific complications related to gastrectomy even many years after the surgery. A compilation of postoperative complications encountered after gastrectomy is called as post-gastrectomy syndromes. With the improvement in medical technology and new chemotherapeutic regimens, the perioperative mortality is decreased and the survival of these patients increased. The increase in survival brings new issues about dieting, exercise, psychological support and so on. The life-threatening diseases like cancer evokes spiritual needs of the patients more frequently. After the survival, many patients with cancer feel more spiritual and pious and want to perform their religious practices.

Ramadan fasting is a very important religious pillar of Islam. It is one month of strict prohibition from eating and drinking beside many restrictions like sexual practices and so on starting from the dawn till the sunset. Since it is according to the lunar calendar, it can be during any season of the year. This could extend fasting from 10-12 hours till to 18 hours depending on the geographic location of the place and the time of the year (summer/winter; the proximity to the poles etc.). ${ }^{[5,6]}$

The survivors of gastric cancer patients frequently ask about their religious practices and especially Ramadan fasting. Since they are instructed to eat frequently with small amount of meals, it is a complete change in the dietary habit. Since medical and surgical oncologists feel that it could be harmful for patients to follow the religious practices of Ramadan even how important patients feel about it, the usual practice is to give a strong advice of restraining the patient from Ramadan fasting. Some patients do not accept the advice and still continue with Ramadan fasting. Although, recently the information about whether the patients with chronic diseases like diabetes mellitus can keep the Ramadan fasting accumulated in the literature, ${ }^{[7,8]}$ there is no evidence-based suggestion whether these patients can keep Ramadan fasting. Therefore, we aimed to evaluate the survivors of gastric cancer patients whether they keep Ramadan fasting and what kind of problems encountered related with it.

\section{MATERIAL AND METHOD}

\section{The Patients}

The study was designed as cross-sectional observational study. The ethical committee approval was obtained from Gaziosmanpasa University Faculty of Medicine (18-KAEK-275).
The patients who underwent a curative gastric surgery during the time period of January 2011 to January 2018 were retrieved from electronic archives. ICD-10-CM diagnosis code C16 for gastric cancer and ICD-10-CM diagnosis code Z90. ${ }^{[3]}$ for total gastrectomy or subtotal gastrectomy conditions were used to define the key elements of the gastrectomy. The retrieved files were identified and the demographic and clinical features of the patients were documented. The surviving patients were identified from the system. The patients were reached by a phone call and given information about the study. Those who completed their surgical and oncological treatments, those without metastasis investigated and proven in the last visit, those who were willing to participate in the study were included. The patients who do not wish to participate, who were unable to come to the outpatient department, those who did not finish the treatment, or with local recurrences, and/or metastasis were excluded from the study. The study patients were scheduled for a meeting in surgical oncology outpatient department between January 2019 and January 2020.

\section{The Questionnaire}

A 20 item questionnaire was prepared before-hand. The process of preparing a questionnaire started with a meticulous search for the literature with Ramadan and gastric cancer patients. However, the literature review yielded no study with gastric cancer patients. Then, we extended our search to post-gastrectomy syndrome, eating habits of the gastrectomy patients, dietary suggestions to gastrectomy patients, Ramadan fasting with oncology patients, and eventually Ramadan fasting and sleeve gastrectomy patients. The items retrieved from the literature were discussed in group meetings with surgeons who operated and followed gastric cancer patients. The number of items were increased until the redundancy. Then, the items were grouped and discussed once more in the meetings and the questions and appropriate answers were decided. The draft version of the questionnaire was applied to a small group of healthcare professionals and patients to reveal the clarity and conciseness. The comments and criticisms of pilot patients and healthcare professionals were taken into consideration to develop the final version of the questionnaires. At the end, 20 items questionnaires grouped into 4 categories. The first category contained 4 items related with eating habits after gastrectomy operation, the second, the third, the fourth categories were about the former attitude about fasting, research for advices and what they lived during fasting respectively and contained binary, ranked answers (Table 1).

\section{The Administration}

The questionnaire was administered in outpatient setting in a separate room by a surgeon. The questions were filled as faceto-face interview manner. The administration time roughly took 20 minutes. If there were any signs noticed during the interview or if the patients raise any symptoms, then a routine follow-up visit was ensued. 
Table 1. The questionnaire

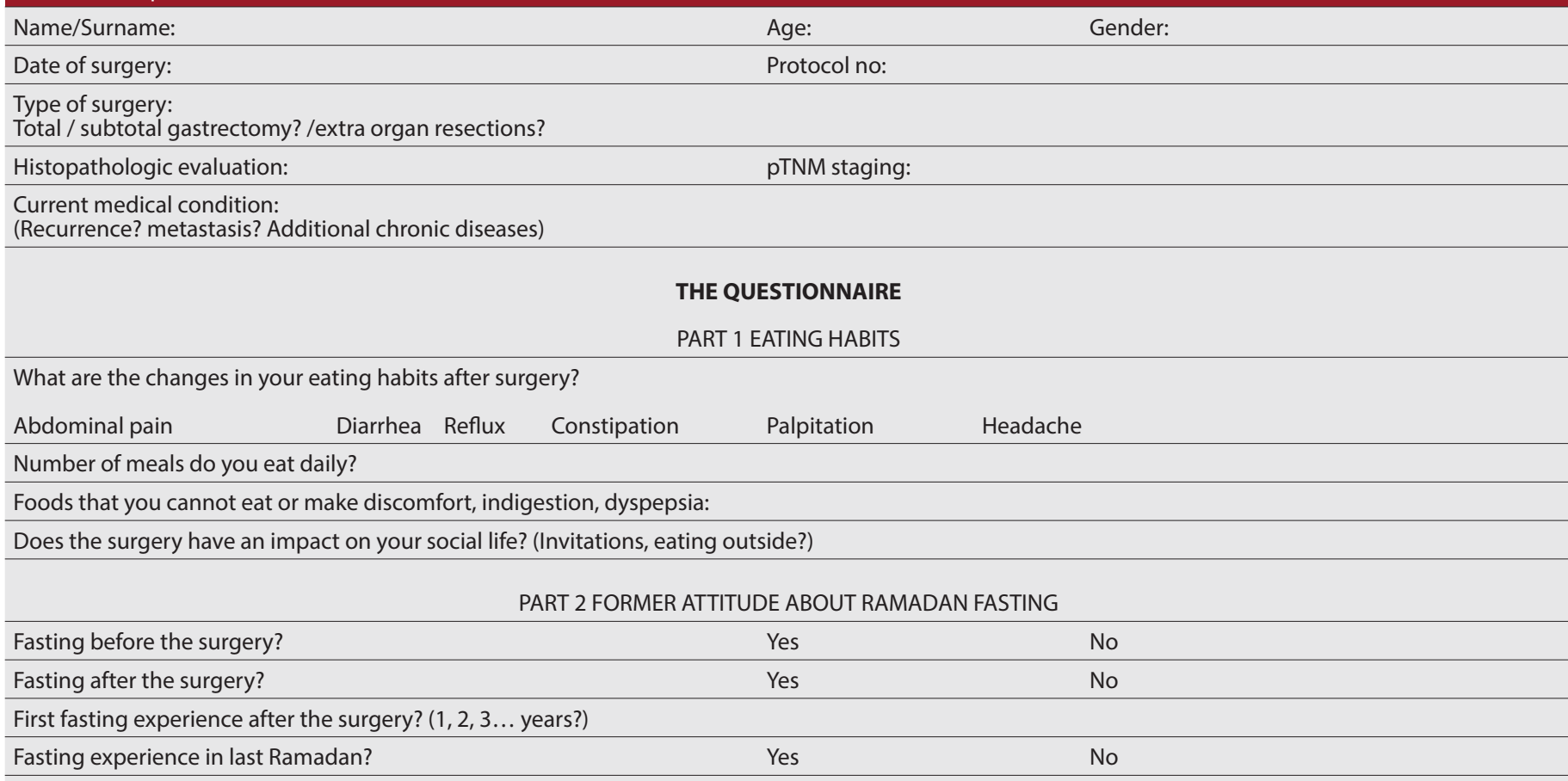

PART 3 RESEARCH FOR ADVICES, SUGGESTIONS

Did you get any suggestions from anyone to fast?

Doctor Nurse Hodja or religiously knowledgeable person Another patient

Friend Internet

Did you get any suggestions from any healthcare professionals?

Family medicine doctor Surgeon Internal medicine specialist

Medical oncologist

What was the suggestion of the doctor? You can fast You cannot fast

Did you consider the doctors' recommendation? $\quad$ Yes

PART 4 WHAT THE PATIENT LIVED DURING FASTING

The patients' weight before and after the last Ramadan?

What you lived during fasting?

Hunger ThirstinessFaintness Diarrhea Nausea/vomitting

Did you ever quit fasting during daytime?

Did you ever fast during the full month of Ramadan?

What measures did you consider to prevent adverse effects?

Eating less Eating frequent at night Less liquid intake More liquid intake

Others:

How long does it last to adapt the normal life after Ramadan fasting?

Did you do your normal work during Ramadan?

Did you request an annual leave or pay-free leave during Ramadan?

Patients who were conceiving to fast in next Ramadan (2019) were invited for at least 2 visits again within one month before and one month after Ramadan. On their arrival, their weight was measured, laboratory test including albumin, haemoglobin, haematocrit, BUN and creatinine levels were obtained. In addition, the patients described the positive or negative health conditions they experienced during the month of Ramadan in the latter visit.

\section{Statistical Analyses}

The quantitative variables were analysed using proportions. Paired Student's t-test was used to compare the measurements at two time points (before and after Ramadan) for albumin, haemoglobin, haematocrit, creatinine, BUN, and body weight. All tests were two-sided. Differences were considered to be statistically significant at $P<0.05$. SPSS version 17.0 (Chicago, IL) software was used for all analyses. 


\section{RESULTS}

For this study, files of 221 patients who underwent total or subtotal gastrectomy with a diagnosis of gastric tumor between January 2011 and January 2018 were retrospectively examined. 68 patients living and meeting the above criteria were reached by phone and invited to the hospital for a faceto-face interview. 52 of these 68 patients were interviewed and questionnaires were conducted.

The study continued with $11(21 \%)$ of these patients who were able to fast in the postoperative period. Among 11 patients included in the study, there were 9 males (82\%) and 2 (18\%) females. The mean age of the patients was 61 (4278). 6 patients had subtotal gastrectomy, 5 patients had total gastrectomy. 3 patients had stage I, 7 patients had stage II and one patient had stage III disease (TNM classification). 5 of these patients were able to complete the 2019 Ramadan fasting, and 6 of them could partially (between 1-7 days).

The weight of these patients was measured before and after Ramadan and routine blood tests were performed. Albumin, haemoglobin, haematocrit, BUN and creatinine values documented before and after Ramadan were compared statistically. Table $\mathbf{2}$ compares the measured weights and laboratory levels of 5 parameters of 11 patients before and after Ramadan.

\begin{tabular}{lccc}
\hline $\begin{array}{l}\text { Table 2. Changes of body weight and laboratory values } \\
\text { Parameters }\end{array}$ & $\begin{array}{l}\text { Before Ramadan } \\
\text { Pafter Ramadan }\end{array}$ & P value \\
\hline $\begin{array}{l}\text { Albumin (g/dL) } \\
\text { Median (range) }\end{array}$ & $4.2(3.6-4.8)$ & $4.2(3.5-4.8)$ & 0.640 \\
$\begin{array}{l}\text { Haemoglobin (g/dL) } \\
\text { Median (range) }\end{array}$ & $13.0(10.1-15.6)$ & $13.5(9.8-15.1)$ & 0.838 \\
$\begin{array}{l}\text { Haematocrit (\%) } \\
\text { Median (range) }\end{array}$ & $39.0(30.0-47.0)$ & $40.0(30.0-44.0)$ & 0.999 \\
$\begin{array}{l}\text { Creatinine (mg/dL) } \\
\text { Median (range) }\end{array}$ & $0.86(0.54-1.08)$ & $0.87(0.59-1.09)$ & 0.208 \\
$\begin{array}{l}\text { BUN (mg/dL) } \\
\text { Median (range) }\end{array}$ & $11.0(7.0-23.0)$ & $15.0(10.0-24.0)$ & 0.002 \\
$\begin{array}{l}\text { Body weight (kg) } \\
\text { Median (range) }\end{array}$ & $65.0(45.0-73.0)$ & $66.0(45.0-74.0)$ & 0.432 \\
\hline
\end{tabular}

There was no weight loss in fasting patients after Ramadan ( $p>0.05)$. In addition, no significant change was found in albumin, haemoglobin, haematocrit and creatinine values after Ramadan ( $p>0.05$ ). However increase in BUN level was statistically significant $(p<0.05)$.

\section{DISCUSSION}

It is a general prejudice among the healthcare professionals and even among the team participating in this study that "gastric cancer patients cannot fast". The fact that $21 \%$ of the patients who suffer from such a severe illness can fast fully or partially, invalidates the prejudice just mentioned in the society. This short course follow up of fasting gastric cancer patients in this study, revealed no significant changes of body weight among the patients. Also albumin, haemoglobin, haematocrit and creatinine values documented after Ramadan fasting revealed no significant changes when compared to previous values which can be interpreted as Ramadan fasting does not cause malnutrition, anaemia or major dehydration. But the increase in BUN levels which is statistically significant is obviously related with some levels of dehydration. The 2019 Ramadan in Turkey was greeted in May and June with high temperatures of spring and summer. Also a mean of 16 hours fasting, which is longer than a 10-12 hours winter Ramadan may contribute to the dehydration. Asegaonkar et al 9 investigated effects of Ramadan fasting on renal function in 33 healthy young individual and stated that among young individuals renal functions are not altered due to Ramadan fasting. Likewise Zahid et al 10 observed no difference in BUN levels of his 56 healthy Muslim subject practicing Ramadan fasting. Factors like the season of fasting, climate, geographic location, daily activity, age and co-morbidities may alter the effects of fasting on the subjects. Sadeghirad et al. ${ }^{[11]}$ specified that Ramadan provides an opportunity to lose weight but weight changes during Ramadan are relatively small due to structured and consistent lifestyle modifications are necessary to achieve weight loss. Studies report similar findings on haemoglobin, haematocrit and albumin levels and state statistically insignificant changes. ${ }^{[12,13]}$

The dietary suggestions after gastrectomy mainly depends on arbitrary suggestions like frequent eating with small amounts of meal. Although it looks rational, it is without strong evidence. Obviously, without the reservoir function of stomach after total or with little after subtotal gastrectomy, the intake of meals more than what the newly formed stomach or jejunum can bear cause distress, nausea and vomiting in most patients. Therefore, in long-term, patients adapt their eating style with usual small and frequent meals with some zip of fluid. But some patients, after some months of adaptation, eat normal amount of meals with three regular intervals with their family. The adaptation process and the duration could vary among patients, their dietary habits and their cultures. Some patients also experienced that some food could be difficult to digest and some could cause them feel sicker and subsequently they also change their diet contents. Therefore, it is obvious that in long run, they could live a normal (compared with their preoperative life) or close to normal life. It shows the power of adaptation in human being. Our questionnaire revealed bulgur wheat, spicy food, rare cooked meat, green and red lentils, uncooked vegetables and salads, extremely hot and cold foods to cause more indigestion and discomfort. Recommendations regarding eating habits after gastrectomy are well-known but dated. Suggestions like smaller portions of meal with having snacks between, well chewing, drinking more fluids, more protein intake is told in a routine manner to every patient having gastrectomy. This 19th century information has been mostly obtained from the follow-up of patients who had surgery for peptic ulcer disease. Nowadays gastrectomy is mostly done for malignancy. Rogers, in his 
post-gastrectomy nutrition review states that there is not a standard post-gastrectomy diet, food restrictions should be minimal and diet manipulations should be individualised to avoid calorie deficit. ${ }^{[14]}$ Therefore when we consider all the above mentioned themes, the information on the subject of what to eat after gastrectomy is questionable.

Multiple variables have different influence levels on cancer mortality like age, gender, co-morbidities, nutritional status, race and inhabited geography. The issues of spirituality and religion have been overlooked for many years in modern medicine. Also little attention has been paid to spirituality in medical education. ${ }^{[15]}$ Due to the increasing prevalence of chronic diseases and cancer, palliative care has recently been more interested and the importance of spirituality has become more clear. 2 meta-analyses concerning more than 1000 study revealed that religious people are physically healthier, lead healthier lifestyles, require fewer health services and adapt more successfully to stress. ${ }^{[16,17]}$ Every health professional has to pay attention to patients' rights and spiritual needs regarding their roles in overall health status considering that spirituality and religion may stand at the centre of these patients' lives.

\section{CONCLUSION}

Muslim population is about a quarter of world population and fasting is one of the pillars of Islam. As such, not only in Muslim countries but also in all over the world health professionals are likely to see fasting patients. Fasting has various health protective effects and is a rule for healthy Muslims but not for patients. Patients who had a curative treatment after a malignant diseases often experience spiritual awareness and may strive for all the rules of their religion. Patients should consult health professionals without hesitation and health professional must be familiar with the physiological and psychological effects of fasting.

\section{ETHICAL DECLARATIONS}

Ethics Committee Approval: The study was approved by the Ethical Board of Gaziosmanpasa University Faculty of Medicine (Approval No: 2018-KAEK-275).

Informed Consent: All participants of the study provided informed consent.

Referee Evaluation Process: Externally peer-reviewed.

Conflict of Interest Statement: The authors have no conflicts of interest to declare.

Financial Disclosure: The authors declared that this study has received no financial support.

Author Contributions: All of the authors declare that they have all participated in the design, execution, and analysis of the paper, and that they have approved the final version.

\section{REFERENCES}

1. WHO report on cancer: setting priorities, investing wisely and providing care for all. Geneva: World Health Organization; 2020. Licence: CC BY-NCSA 3.0 IGO.

2. Kim JH, Kim SS, Lee JH, et al. Early Detection is Important to Reduce the Economic Burden of Gastric Cancer. J Gastric Cancer. 2018;18(1):82-89.

3. Kim $\mathrm{TH}$, Kong SH, Park JH, et al. Assessment of the Completeness of Lymph Node Dissection Using Near-infrared Imaging with Indocyanine Green in Laparoscopic Gastrectomy for Gastric Cancer. J Gastric Cancer. 2018;18(2):161-171.

4. Isik A, Okan I, Firat D, Yilmaz B, Akcakaya A, Sahin M. A new prognostic strategy for gastric carcinoma: albumin level and metastatic lymph node ratio. Minerva Chir. 2014;69(3):147-53.

5. Trepanowski JF, Bloomer RJ. The impact of religious fasting on human health. Nutr J. 2010;9(1):57.

6. Pakkir Maideen NM, Jumale A, I.H. Alatrash J, Ahamed Abdul Sukkur A Health Benefits of Islamic Intermittent Fasting. J Fasting Health. 2017; 5(4): 162-171.

7. Gnanou JV, Caszo BA, Khalil KM, Abdullah SL, Knight VF, Bidin MZ. Effects of Ramadan fasting on glucose homeostasis and adiponectin levels in healthy adult males. J Diabetes Metab Disord. 2015; 14(1):55.

8. Patterson RE, Laughlin GA, LaCroix AZ, et al. Intermittent fasting and human metabolic health. J Acad Nutr Diet. 2015; 115(8):1203-12.

9. Asegaonkara SB, Kareemb I, Bavikar J, et al. Effect of Ramadan Fasting on Renal Function Markers in Healthy Adults From Aurangabad. WIMJOURNAL 2014; 1(1): 2349-2910.

10. Mohammed ZJ.The influence of ramadan fasting on some hematological and biochemical parameters in healthy adult males Iraqi National J. for Nursing Specialties. 2011;24(1):45-51.

11. Sadeghirad B, Motaghipisheh S, Kolahdooz F, Zahedi MJ, Haghdoost AA Islamic fasting and weight loss: a systematic review and meta-analysis. Public Health Nutr. 2014;17(2):396-406

12. Al Hourani HM, Atoum MF, Akel S, Hijjawi N, Awawdeh S. Effects of Ramadan fasting on some haematological and biochemical parameters. Jordan J Biologic Sci 2009; 2(3):103-8.

13. Alam I, Gul R, Chong J, et al. Recurrent circadian fasting (RCF) improves blood pressure, biomarkers of cardiometabolic risk and regulates inflammation in men. J Transl Med 2019;217: 272.

14. Rogers C. Postgastrectomy nutrition. Nutr Clin Pract 2011;26(2):126-36.

15. Twycross R. Introducing palliative care. 3rd ed. Oxford: Radcliffe Medical Press, 1999

16. Koenig HG. Religion, spirituality and medicine: application to clinical practice. JAMA 2000; 284:1708-9

17. Hummer R, Rogers R, Nam C, Ellison C. Religious involvement and US adult mortality. Demography 1999; 36:273-85. 